\title{
KAJIAN POTENSI BIOSURFAKTAN ISOLAT BAKTERI TERSELEKSI UNTUK DIMANFAATKAN DALAM BIOREMEDIASI TANAH TERCEMAR MINYAK BUMI
}

\author{
Nida Sopiah ${ }^{1}$, Mulyono $^{1}$, Susi Sulistia ${ }^{1}$ \\ (Diterima tanggal : \\ ; Disetujui tanggal : \\ )
}

\begin{abstract}
Biosurfactants are surface-active substances derived from living organisms, especially microorganisms. Bacterial strains used are consisted of four bacterial strains, coded I, LESR 1, LESR 2 and LESR 3, which previously isolated from petrochemical wastes. Two isolates, coded I and LESR 3 respectively, were potential biosurfactant producers. Both were identified as Gram-positive bacteria. Isolate I is a mixture of streptobacilli and diplobacilli, while isolate LESR3 is streptobacilli. Both isolates were able to emulsify gasoline at temperature of $28^{\circ} \mathrm{C}$ and $80^{\circ} \mathrm{C}$, respectively, at salinity of $4 \%$. The biosurfactant ability to increase the solubility of hydrophobic compounds enhances the bacterial performance in remediation of oil-contaminated soil.
\end{abstract}

Keywords: Biosurfactant, remediation, microorganisms, oil-contaminated soil

\begin{abstract}
ABSTRAK
Biosurfaktan merupakan bioproduk yang dihasilkan makhluk hidup, khususnya mikroba, yang mempunyai sifat dapat menurunkan tegangan permukaan dan antar muka. Isolat bakteri yang digunakan terdiri dari empat isolat bakteri dengan kode isolat I, LESR 1, LESR 2 dan LESR 3, yang diisolasi dari tanah yang tercemar minyak bumi. Dari hasil pengamatan yang dilakukan, diketahui bahwa isolat I dan LESR3 merupakan isolat yang berpotensi menghasilkan biosurfaktan. Kedua isolat ini merupakan bakteri Gram positif. Uji morfologi sel bakteri diketahui bahwa isolat I merupakan campuran bakteri yang berbentuk batang berantai (streptobasil) dan batang berpasangan (diplobasil), sedangkan isolat LESR3 merupakan bakteri berbentuk batang berantai (streptobasil). Hasil uji emulsifikasi terhadap bensin, kedua bioproduk isolat ini mampu melakukan proses emulsi pada suhu kamar, suhu $80^{\circ} \mathrm{C}$ ataupun pada salinitas $4 \%$. Kemampuan biosurfaktan tersebut dapat membantu kinerja bakteri dalam meremediasi tanah yang tercemar minyak karena biosurfaktan mampu meningkatkan kelarutan senyawa hidrofobik
\end{abstract}

Kata kunci : Biosurfaktan, remediasi, mikroba, tanah tercemar minyak

\section{PENDAHULUAN}

Keputusan Menteri Negara Lingkungan Hidup nomor 128 Tahun 2003 tentang tatacara dan persyaratan teknis pengolahan limbah minyak bumi dan tanah terkontaminasi oleh minyak bumi secara biologis menyatakan bahwa limbah minyak bumi yang dihasilkan usaha atau kegiatan minyak, gas dan panas bumi atau kegiatan lain yang menghasilkan limbah minyak bumi merupakan limbah bahan berbahaya dan beracun yang memiliki potensi menimbulkan pencemaran dan atau kerusakan lingkungan oleh karena itu perlu dilakukan pengelolaan dengan baik ${ }^{(1)}$. Salah satu upaya pengolahan limbah minyak bumi dan tanah terkontaminasi oleh minyak bumi dapat dilakukan dengan pengolahan secara biologis (bioremediasi). Bioremediasi merupakan suatu teknologi yang ramah lingkungan, yang mana mikroba memegang peranan yang sangat penting dalam proses degradasi limbah biologi. Salah satu faktor yang menentukan keberhasilan aplikasi bioremediasi adalah tersedianya mikroba yang mampu mendegradasi limbah tersebut.

Mikroba berinteraksi dan beradaptasi dengan

${ }^{1}$ Balai Teknologi Lingkungan BPPT Gedung 412 Kawasan Puspiptek Serpong, 15314. Telp 021-7560919/7563116 
lingkungannya akan memberikan efek positif maupun negatif. Hal ini didasarkan bahwa di antara mikroba itu ada yang mampu menghasilkan bahan kimia berupa biosurfaktan, biopolimer, biofilm, biosolven, bioasam, dan biogas ${ }^{(2)}$.

Ada beberapa pendekatan yang dapat dilakukan untuk meningkatkan kinerja mikroba dalam meremediasi lahan tercemar minyak yaitu memperbaiki kondisi mikro lingkungan (intrinsic) dan pendekatan yang lainnya adalah dengan menambahkan strain-starin unggulan (bioaugmentation). Perbaikan kondisi lingkungan dapat dilakukan dengan menambahkan bahan tertentu (umumnya nutrient) atau dengan cara memperbaiki suplai oksigen. Teknik bioaugmentation dilakukan dengan melakukan pengembangan strain-strain unggul (3) yang menghasilkan biosurfaktan yang berfungsi untuk meningkatkan emulsifikasi hidrokarbon, sehingga kontak antara bakteri dengan hidrokarbon akan lebih efektif.

Biosurfaktan memiliki karakteristik mereduksi tegangan permukaan dan antarmuka dengan mekanisme yang sama seperti pada surfaktan kimia. Secara struktural, biosurfaktan merupakan kelompok molekul dengan gugus permukaan aktif yang beragam. Biosurfaktan menjadi produk mikroba bernilai tinggi karena aksinya yang spesifik, toksisitas rendah, biodegradibilitas tinggi, efektif pada berbagai suhu, $\mathrm{pH}$, salinitas dan struktur uniknya beragam dibandingkan surfaktan sintetik ${ }^{(4)(5)}$.

Biosurfaktan yang dihasilkan dapat diklasifikasikan ke dalam delapan kelompok yaitu biosurfaktan jenis glikolipid, lipopeptida/ lipoprotein, fosfolipid, antibiotik aktif permukaan, asam lemak/lipid netral, surfaktan polimer, ornitin-lipid, surfaktan partikulat ${ }^{(4)}$. Faktor-faktor yang sangat berpengaruh terhadap produksi biosurfaktan adalah sumber karbon, sumber nitrogen, trace element dan faktor lingkungan seperti $\mathrm{pH}$, suhu, agitasi, dan ketersediaan oksigen. Beberapa mikroba penghasil biosurfaktan yang pernah diteliti diantaranya adalah Pseudomonas sp, Bacillus subtilis, Bacillus licheniformis strain JF-2, Pseudomonoas aeruginosa, dan Pseudomonas fluorescens $^{(2),(6)}$.

Tujuan dari penelitian ini adalah untuk mengkaji potensi biosurfaktan dari isolat yang telah diseleksi dari beberapa isolat potensial yang berasal dari tanah tercemar minyak bumi.

\section{METODOLOGI}

\section{Bahan}

Isolat bakteri

Isolat bakteri yang digunakan sebanyak empat isolat dengan kode I, LESR1, LESR2 dan LESR3. Isolat ini merupakan koleksi Isolat dari Balai Teknologi Lingkungan BPPT yang diisolasi dari tanah tercemar minyak bumi yang berasal dari Kabupaten Siak, Riau.

Media Percobaan

Media percobaan yang digunakan dikelompokkan dalam dua kelompok.

Media Bushnell-Haas yang dimodifikasi dengan Yeast Extract $0.12 \%$ ditambah gliserol 2\%, media Bushnell-Haas lainnya hanya ditambah gliserol $2 \%$.

Kedua media tersebut digunakan untuk mendapatkan media pertumbuhan yang cocok bagi bakteri untuk menghasilkan biosurfaktan.

Komposisi dari media Bushnell-Haas adalah sebagai berikut : $\mathrm{KH}_{2} \mathrm{PO}_{4} 0.5$ gram, $\mathrm{K}_{2} \mathrm{HPO}_{4}$ 
0.5 gram, $\mathrm{FeCl}_{3} 0.025$ gram, $\mathrm{CaCl}_{2} 0.01$ gram, $\mathrm{MgSO}_{4} 0.1$ gram.

Bahan-bahan tersebut di atas dilarutkan dengan $500 \mathrm{~mL}$ aquadest ke dalam botol media dan dihomogenkan untuk kemudian disterilisasi dengan autoklaf pada suhu 120 ${ }^{\circ} \mathrm{C}$ dan tekanan 15 psi.

Media Nutrient Agar (NA), Kedalam 1 $\mathrm{L}$ akuades dimasukkan $15 \mathrm{~g}$ pepton, $3 \mathrm{~g}$ ekstrak ragi, 6 g NaCl, 1 g glukosa, dan 15 g agar sambil dipanaskan dan diaduk hingga larut. Setelah semua bahan larut, media disterilisasi pada tekanan 15 psi selama 15 menit. Media NA yang telah steril kemudian dituang ke dalam cawan petri steril dan dibiarkan membeku. Masing-masing isolat bakteri diinokulasikan ke media NA dalam cawan petri dengan metode gores kemudian diinkubasi selama 24 jam pada suhu $28^{\circ} \mathrm{C}$.

Media NA digunakan untuk menumbuhkan isolat pada media padat untuk selanjutnya isolat tersebut digunakan untuk diidentifikasi morfologi sel bakterinya.

\section{Alat yang digunakan}

Neraca analitik digunakan untuk menimbang secara analitis bahan-bahan media yang diperlukan untuk media tumbuh bakteri. Autoklaf digunakan untuk sterilisasi media tumbuh bakteri(Bushnell-Haas dan Nutrient Agar). Oven digunakan untuk sterilisasi peralatan gelas (tabung reaksi, cawan petri, pipet takar $10 \mathrm{~mL}$ dan pipet takar $5 \mathrm{~mL}$ ).

\section{Prosedur Kerja :}

Inokulasi bakteri

- Disiapkan sebanyak delapan buah labu Erlenmeyer 250 mL. Empat labu Erlenmeyer ini diisi dengan $100 \mathrm{~mL}$ media
Bushnell-Haas yang telah ditambahkan dengan $2 \%$ gliserol dan Yeast extract 0,12\% dan empat buah labu Erlenmeyer lainnya diisi $100 \mathrm{~mL}$ media BushnellHaas cair yang hanya ditambah gliserol 2\%. Ke delapan labu Erlenmeyer ini selanjutnya disterilisasi dengan autoklaf pada suhu $120^{\circ} \mathrm{C}$ dan tekanan 15 psi selama 15 menit. Media diangkat dari autoklaf apabila suhu autoklaf telah mencapai suhu kamar. Inokulasi keempat isolat yaitu isolat I, LESR 1, LESR 2 dan LESR 3, dilakukan dengan mengambil masing-masing sebanyak satu ose secara aseptik dimasukkan kedalam kedua media Bushnell-Haas yang berbeda dan diletakkan di atas shaker selama 1x24 jam.

Pengujian indeks emulsifikasi

- Setelah 1x24 jam keempat bakteri dikulturkan pad media Bushnell-Haas yang dimodifikasi dengan yeast extract $0,12 \%$ ditambah gliserol $2 \%$ dan media Bushnell-Haas lainnya yang dimodifikasi hanya dengan penambahan gliserol $2 \%$, masing-masing kultur pada kedua media selanjutnya disentrifugasi untuk memisahkan biakan bakteri dengan supernatannya. Supernatan yang diperoleh diuji indeks emulsifikasinya dengan cara menambahkan $1 \mathrm{~mL}$ bensin pada masing-masing $3 \mathrm{~mL}$ supernatan. Masing-masing campuran supernatan dan bensin ini selanjutnya dikocok menggunakan alat vortex, dan disimpan pada 3 perlakuan yang berbeda yaitu pada suhu kamar, suhu $80^{\circ} \mathrm{C}$ dan larutan salin ( $\mathrm{NaCl} 4 \%$, suhu kamar). 

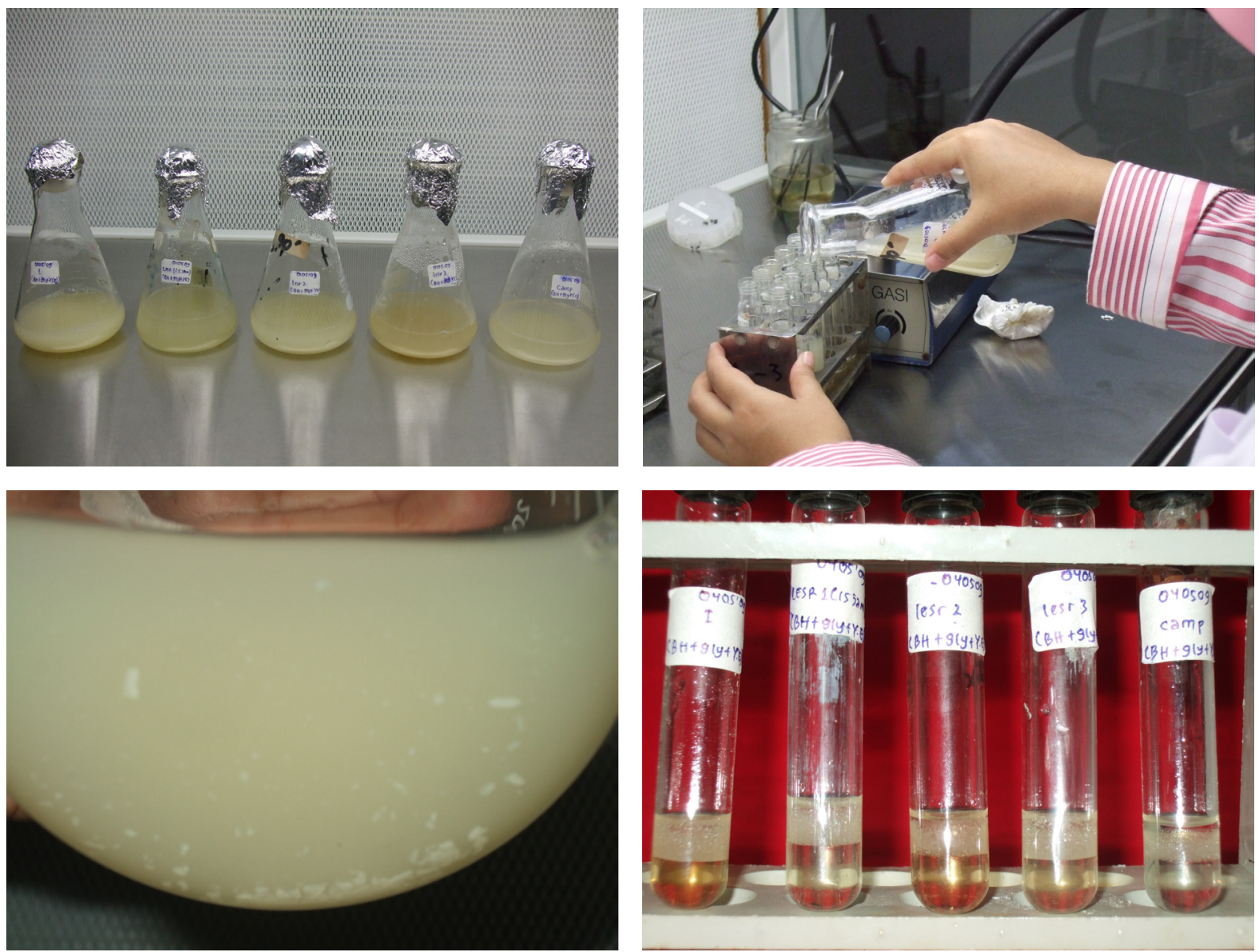

Gambar 1. Inokulasi Bakteri biosurfaktan dan Uji Emulsifikasi biosurfaktan.

Identifikasi morfologi sel bakteri

Koloni bakteri yang telah diinokulasikan selama 1 x 24 jam diambil dengan menggunakan jarum ose secara aseptis, dipindahkan ke atas slide bersih yang telah diberi setetes air di atasnya, kemudian dibuat apusan kering. Apusan diwarnai dengan kristal violet selama 1 menit kemudian dicuci dengan akuades. Apusan ditetesi dengan iodine selama 2 menit, dialiri dengan akuades, dicuci dengan alkohol 95\% setetes demi setetes hingga tetesan alkohol menjadi bening. Apusan dibilas lagi dengan akuades kemudian diwarnai dengan safranin selama 45 detik,

dibilas lagi, dan diblot dengan kertas hisap secara hati-hati. Apusan diamati di bawah mikroskop dengan perbesaran objektif 100x dengan bantuan minyak imersi.

\section{HASIL DAN PEMBAHASAN}

Bakteri mampu mensisntesis tipe atau mengekskresikan biosurfaktan yang berbeda ketika ditumbuhkan pada beberapa sumber karbon maupun nitrogen dengan komposisi yang berbeda. Perbedaan dari jenis dan komposisi ini akan menyebabkan peningkatan produksi pada beberapa jenis bakteri, serta menyebabkan perubahan komposisi biosurfaktan yang dihasilkan.

Hidrokarbon dan substrat tak-larut air (hidrofobik) dapat menginduksi produksi biosurfaktan, contohnya n-alkana, minyak zaitun, heksadekana, minyak biji bunga matahari, sedangkan penggunaan glukosa dan 
metabolit primer lainnya dapat menyebabkan terjadinya represi katabolik $k^{(4)}$.

Penambahan sumber nitrogen yang digunakan juga dapat mempengaruhi biosurfaktan yang dihasilkan. Sumber nitrogen yang biasa digunakan dalam kultur bakteri adalah garam amonium, nitrat, dan urea. Produksi biosurfaktan akan meningkat dengan adanya penambahan asam amino (Asp, Glu, Asn, Gly). Faktor lain yang juga perlu diperhatikan adalah faktor lingkungan yaitu $\mathrm{pH}$, suhu, agitasi, dan ketersediaan oksigen.

Tabel 1. Pengaruh media tumbuh pada bakteri terhadap produksi biosurfaktan

\begin{tabular}{|l|c|c|}
\hline $\begin{array}{c}\text { Kode } \\
\text { Isolat }\end{array}$ & $\begin{array}{c}\text { Media Bushnell- } \\
\text { Haas + gliserol }\end{array}$ & $\begin{array}{c}\text { Media Bushnell- } \\
\text { Haas + gliserol + } \\
\text { yeast extract }\end{array}$ \\
\hline I & - & + \\
\hline LESR1 & - & + \\
\hline LESR2 & - & + \\
\hline LESR3 & - & + \\
\hline
\end{tabular}

Keterangan :

$(-)=$ bakteri tidak menghasilkan biosurfaktan

$(+)=$ bakteri menghasilkan biosu

Pada Tabel 1, dapat diinterpretasikan bahwa pengaruh media tumbuh terhadap produksi biosurfaktan yang diekskresikan bakteri sangat berpengaruh nyata. Penambahan yeast extract pada media Bushnell-Haas dapat mempengaruhi produksi biosurfaktan yang dihasilkan oleh keempat isolat yang diujikan. Hal ini ditunjukkan dengan adanya emulsifikasi dari masing-masing supernatan pada media cair Bushnell-Haas yang ditambahkan yeast extract $0.12 \%$ dan gliserol $2 \%$.

Keempat isolat bakteri pada media BushnellHaas yang dimodifikasi dengan penambahan yeast extract menghasilkan uji emulsifikasi positif sedangkan pada media Bushnell-Haas tanpa modifikasi penambahan yeast extract memberikan uji emulsifikasi negatif.

Yeast extract mengandung asam-asam amino yang mampu menginduksi bakteri untuk menghasilkan biosurfaktan yang ditunjukkan dengan hasil positif pada uji emulsifikasi.

Emulsifikasi terjadi karena adanya senyawa biosurfaktan yang dihasilkan oleh bakteri atau diekskresikan secara ekstrasel yang memiliki sifat aktif-permukaan, mengandung bagian hidrofobik dan hidrofilik yang memungkinkan terakumulasi di antara fase cair, mampu membentuk misel yang mampu mereduksi tegangan permukaan dan antarmuka sehingga meningkatkan kelarutan senyawa yang kurang larut dalam air. Dari data tersebut maka media BushnellHaas yang ditambahkan gliserol $2 \%$ dan yeast extract $0,12 \%$ digunakam untuk pengujian emulsifikasi terhadap senyawa hidrofobik dari bakteri-bakteri yang diuji.

Uji biosurfaktan pada supernatan yang dihasilkan dari inokulasi masing-masing bakteri pada media Bushnell-Haas + gliserol + yeast extract terhadap keempat isolat tunggal I, LESR1, LESR2, dan LESR3, menunjukkan bahwa supernatan yang dihasilkan dari isolat I dan LESR3 mampu mengemulsikan bensin baik pada suhu kamar, suhu $80^{\circ} \mathrm{C}$ maupun dalam lingkungan yang salin (4\%), sedangkan LESR 1 dan LESR 2 setelah disimpan selama 1 x 24 jam hampir tidak mengalami emulsifikasi. Uji biosurfaktan terhadap bakteri campuran LESR1, LESR2 dan LESR3 (Mix Culture) mengalami emulsifikasi pada masing-masing perlakuan akan tetapi daya emulsifikasinya lebih rendah daripada kode isolat I dan LESR3 (tabel 2) 
Dari data tersebut diatas tampak bahwa enzim ekstraselular yang dihasilkan oleh keempat isolat baik tunggal maupun campuran memberikan respon yang hampir sama.

Tabel 2. Kemampuan emulsifikasi bakteri t erhadap bensin setelah disimpan selama $1 \times 24$ jam

\begin{tabular}{|l|c|c|c|}
\hline $\begin{array}{c}\text { Kode } \\
\text { Isolat }\end{array}$ & $\begin{array}{c}\text { Bensin, } \\
27^{\circ} \mathrm{C}\end{array}$ & $\begin{array}{c}\text { Bensin, } \\
80^{\circ} \mathrm{C}\end{array}$ & $\begin{array}{c}\text { Bensin }, \\
\mathrm{NaCl} 4 \%, \\
27^{\circ} \mathrm{C}\end{array}$ \\
\hline $\mathrm{I}$ & ++ & ++ & ++ \\
\hline LESR1 & $+/-$ & - & - \\
\hline LESR2 & $+/-$ & - & - \\
\hline LESR3 & ++ & ++ & ++ \\
\hline MixLESR3 & + & + & + \\
\hline
\end{tabular}

Keterangan :

$(-) \quad=$ tidak terjadi emulsifikasi

$(+/-)=$ emulsifikasi terjadi sedikit

$(+)=$ emulsifikasi terjadi sedang

$(++)=$ emulsifikasi terjadi banyak

Pengaruh suhu dan salinitas terhadap aktivitas biosurfaktan untuk mengemulsikan senyawa hidrofobik tidak memberikan efek negatif, sehingga biosurfaktan tersebut baik pada suhu kamar, maupun suhu $80^{\circ} \mathrm{C}$ masih mampu mengemulsikan senyawa hidrofobik, begitu pula pada lingkungan yang mempunyai salinitas yang cukup tinggi, biosurfaktan masih mampu bekerja untuk mengemulsikan senyawa hidrofobik.

Identifikasi koloni dari keempat isolat menunjukkan bahwa isolat I mempunyai morfologi sel bakteri berupa batang berantai (streptobasil), dan sebagian lagi berupa batang berpasangan (diplobasil), dari uji pewarnaan Gram yang diamati dengan mikroskop, isolat I ini termasuk kedalam golongan Gram positif, hal ini terlihat dari warna sel bakteri berwarna merah keunguan.

Isolat LESR1 dan LESR3 mempunyai morfologi sel bakteri berupa batang berantai (streptobasil) dan dari uji pewarnaan Gram yang diamati dengan mikroskop, kedua isolat ini termasuk kedalam golongan Gram positif, hal ini terlihat dari warna sel bakteri berwarna merah keunguan.

Isolat LESR2 mempunyai morfologi sel bakteri berupa bulat (coccus) dan dari uji pewarnaan Gram yang diamati dengan mikroskop, isolat LESR 2 ini termasuk kedalam golongan Gram negatif, hal ini terlihat dari warna sel bakteri berwarna merah pucat (tabel 3).

Tabel 3. Identifikasi Morfologi sel bakteri

\begin{tabular}{|c|c|c|}
\hline Kode Isolat & $\begin{array}{c}\text { Morfologi Sel } \\
\text { Batang } \\
\text { berantai } \\
\text { (streptobasil) } \\
\text { sebagian } \\
\text { batang } \\
\text { berpasangan } \\
\text { (diplobasil) }\end{array}$ & Gram \\
\hline LESR1 & $\begin{array}{c}\text { Batang } \\
\text { berantai } \\
\text { (streptobasil) }\end{array}$ & + \\
\hline LESR2 & Bulat (kokus) & - \\
\hline & $\begin{array}{c}\text { Batang } \\
\text { berantai } \\
\text { (streptobasil) }\end{array}$ & + \\
\hline
\end{tabular}




\section{KESIMPULAN}

Perbedaan dari jenis dan komposisi media tumbuh bakteri akan mempengaruhi produksi dan enzim ekstraselular yang diekskresikan oleh bakteri.

Pengaruh suhu dan salinitas terhadap aktivitas biosurfaktan yang dieksresikan isolat I dan LESR3 memberikan respon yang positif dalam mengemulsikan senyawa hidrofobik.

Biosurfaktan mempunyai sifat dapat menurunkan tegangan permukaan dan antarmuka, tolerans terhadap $\mathrm{pH}$, suhu, dan ion.

Biosurfaktan meningkatkan kelarutan senyawa hidrofobik sehingga mampu meningkatkan dan mempercepat laju degradasi polutan oleh mikroba. Pemanfaatan biosurfaktan dapat digunakan dalam meremediasi tanah maupun air yang tercemar minyak karena biosurfaktan mampu meningkatkan emulsifikasi hidrokarbon, sehingga kontak antara bakteri dengan hidrokarbon akan lebih efektif.

\section{UCAPAN TERIMA KASIH}

Penulis mengucapkan terima kasih kepada rekan-rekan Balai Teknologi Lingkungan BPPT, khususnya rekan-rekan di Laboratorium Mikrobiologi dan Proses atas fasilitas dan keramahan yang diberikan. Penulispun menghaturkan ucapan terima kasih kepada mbak Eko dan mas Sandri atas jerih payahnya dalam mengisolasi bakteri sehingga kajian terhadap keempat isolat ini dapat terlaksana.

\section{DAFTAR PUSTAKA}

1. Keputusan Menteri Negara Lingkungan Hidup Nomor 128 Tahun 2003 tentang Tatacara dan Persyaratan Teknis Pengolahan Limbah Minyak Bumi dan Tanah Terkontaminasi oleh Minyak Bumi secara Biologis, 2003.

2. Kadarwati,S., Sri A.R. dan Sugihardjo, (2004), Lembaran Publikasi, LEMIGAS vol 38 (2)

3. Kardena, E. 2003, Persistent Organic Pollutans (POPs) dan Peran Organisme dalam Proses Detoksifikasi di Lingkungan, Buku Abstrak "Peran Mikrobiologi dalam Pemanfaatan Biodiversitas Tropis bagi Pengembangan Industri, Pertanian, Lingkungan dan Pengendalian Penyakit", Pertemuan Ilmiah tahun 2003, Perhimpunan Mikrobiologi Indonesia, hal. 28-29.

4. K. Muthusamy, S. Gopalakrishnan, T.K. Ravi,dan P. Sivachidambaram (2008), Biosurfactants: Properties, commercial, production and application, Current Sci.Vol(94(6) : 736-747

5. Al-Araji, L., Abd.-Rahman, R.N.Z.R., Basri, M. dan Salleh, A.B. 2007, Microbial surfactant. Asia Pacific J. Mol. Biol. and Biotech. (15) : 99-105.

6. G. C. Okpokwasili dan A. A. Ibiene (2006), Enhancement of recovery of residual oil using a biosurfactant slug, African Journal of Biotechnology Vol. 5 (5), 453-456 